\title{
Tempo, Folguedos e Narrativas nos circuitos da cultura popular em Sergipe
}

\author{
Mesalas Ferreira Santos
}

Universidade Federal do Rio de Janeiro

Resumo: O texto articula a relação entre folguedos folclóricos, temporalidade e narrativa, através da perspectiva de um mestre da cultura popular nordestina. E, como estes elementos o auxilia na orientação de sua conduta naquilo que entende ser "mestre" na cultura popular.

Palavras-chave: Narrativa; Folguedos; Temporalidade; Laranjeiras; Zé Rolinha. 


\title{
Time, Folguedos and Narratives in the circuits of popular culture in Sergipe
}

\begin{abstract}
The text articulates the relationship between folklore folklores, temporality and narrative, through the perspective of a master of popular culture of the Northeast. And, as these elements aid him in guiding his conduct in what he understands to be "master" in popular culture.
\end{abstract}

Keywords: Narrative; Folguedos; Temporality; Laranjeiras; Zé Rolinha.

\section{Tiempo, Folguedos y Narrativas en los circuitos de la cultura popular en Sergipe}

Resúmen: El texto articula la relación entre folguedos folclóricos, temporalidad y narrativa, a través de la perspectiva de un maestro de la cultura popular nordestina. Y, como estos elementos lo auxilia en la orientación de su conducta en lo que entiende ser "maestro" en la cultura popular. Rolinha.

Palabras clave: Narrativa; Folguedos; Temporal; Laranjeiras; Zé 
Para ir à cidade de Laranjeiras, além de carro próprio, é bastante utilizado o transporte público intermunicipal e "táxi lotação". A cidade é localizada na região do Vale do Cotinguiba, território leste do estado de Sergipe (SE), distante dezenove quilômetros da capital. Após sair do centro de Aracaju, o transporte seguiu pela rodovia BR $101 \mathrm{com}$ paisagem no horizonte preenchida por morros e colinas, cobertas por pastos onde se alimentavam alguns belos gados, que passavam conforme o ritmo do ônibus. Em 55 minutos fez-se o trajeto de 23 quilômetros, interligando Aracaju a Laranjeiras. Desci no pequeno terminal rodoviário municipal, próximo ao Largo do Quaresma, um dos espaços de referência para os laranjeirenses: um descampado beirando o rio Cotinguiba, local onde geralmente ocorrem brincadeiras e ritos de grupos folclóricos.

Telefonei para José Ronaldo de Meneses, conhecido como Zé Rolinha, previamente para marcar uma visita. Quando me aproximei de sua casa, percebi que ele já estava me esperando na porta sentado na cadeira. A relação que Zé Rolinha desenvolveu com pesquisadores e estudiosos de folclore e cultura popular sergipana, ao longo de vinte e cinco anos à frente de folguedos, colocouo em uma posição defensiva. Disponibilizava pouco do seu tempo. Sempre disposto para uma conversa rápida, e quando se animava para falar um pouco mais, desabafava sobre suas dificuldades pessoais na manutenção dos folguedos que liderava: a "Chegança Almirante Tamandaré" e os "Lambe-Sujos". Quando falávamos sobre o processo de transmissão da cultura popular local, por exemplo, dava às costas e saía embora murmurando palavras. Dessa maneira, foi difícil obter maiores informações sobre os folguedos. No entanto, com o tempo isso mudou. As conversas utilizadas nesse artigo priorizaram o recorte temporal entre 2007e 2009, e 2013-2015, anos em que compartilhei experiências mais próximas e sempre em contato com Zé Rolinha, bem como grupos folclóricos, com seus brincantes e líderes na cidade de Laranjeiras, sempre com respeito e prévio agendamento.

Conforme a confiança se estabelecia através de processo de experiências compartilhadas participando de ensaios e conversas com Zé Rolinha, brincantes e moradores locais ouvi muitas histórias sobre os folguedos. Narradas de modo mais espontâneo, as conversas mostravam complementares e mais profundas. A narrativa colocada por Zé Rolinha para descrever a si mesmo e seus brinquedos, invariavelmente, abordava alguns aspectos, como: o processo de aprendizagem na cultura popular local; tensões e conflitos no processo de transmissão e aprendizagem da cultura popular, sobretudo pós políticas culturais de patrimonialização imaterial; as memórias das fronteiras espaciais urbanas, rememorando tensões étnico-raciais nas relações da cidade e, no meio de tudo isso, os folguedos interligando mundos. Suas falas sobre os folguedos, invariavelmente, remetiam à própria história social de Laranjeiras.

A mediação de Zé Rolinha nos folguedos comportava ação ritual que envolvia performances e narrativas que remetia à cultura e história local. A tentativa de um fragmento da biografia de Zé Rolinha não é conformidade com ilusão retórica, mas está relacionada metodologicamente a uma dinâmica que envolve acontecimento e estrutura. O que fica circunscrito na biografia do Zé Rolinha, contudo, é uma tentativa de conexão de acontecimentos dessa singularidade com os processos gerais que envolvem o folclore e a história local. 
As conversas com Zé Rolinha, especialmente sobre os folguedos Chegança e Lambe-Sujos chamou atenção em sua fala a representatividade de ordenação do tempo local através das festas. Discurso reproduzido também na fala de demais líderes de folguedos tradicionais local, como: Deca, líder do Cacumbi, Bárbara, líder das Taieiras; Sales e Nadir, líderes do São Gonçalo. Enfatizavam constantemente características de um passado da cidade de Laranjeiras com características de um tempo onde tudo era muito próspero, porém sem precisar quando historicamente ocorreu esse passado áureo.

Nessas conversas, os líderes usavam o termo "tradição", ou "tradicional" para se referirem aos folguedos que comandavam. O uso dessa categoria era sempre relacionado a um passado próspero de Laranjeiras. Seguindo (LYOTARD, 1985: 34) o entendimento do termo "tradição" nas culturas populares "diz respeito ao tempo, não ao conteúdo", que se prende a situações de constantes encaixes e desencaixes daquilo que precisa ser lembrado ou repetido constantemente, "o tempo todo, porque são esquecidas o tempo todo". No entanto, aos poucos compreendi que o lugar do passado rememorado através de narrativas da história de Laranjeiras era geralmente associado a um tempo, uma temporalidade dos folguedos.

Utilizei o recurso da "descrição densa" (GEERTZ, 2008: 07) com foco no aspecto interpretativo da descrição que forneceram sobre a cultura local, com suas formas simbólicas e significados. O intuito no contato com os folguedos, tem a ver com apreensão das formas simbólicas que os brincantes utilizavam para conceituar a sua realidade, onde a descrição torna-se uma interpretação de uma interpretação.

\section{O tempo das festas e dos folguedos}

Dados do IBGE, a partir do Censo 2010, a cidade de Laranjeiras possuía área territorial $162,80 \mathrm{Km}^{2}$ e uma população residente total de 26.902 mil pessoas1, dividida em população urbana com 21.257 habitantes, representando 79\%, e população rural com 5.645 habitantes, representando 21,0\%. Orientavam suas economias de acordo com a demanda por mão-de-obra temporária do setor industrial, em especial orientando ação para o trabalho braçal do corte e manejo da colheita de cana de açúcar nas grandes plantações dos municípios circunvizinhos.

A maioria dos brincantes de folguedos tradicionais residiam nas comunidades rurais do município. Os trabalhadores rurais de Laranjeiras seguiam o calendário de plantio e colheita da cana, para contratação entre os meses de abril e novembro. Quando não estavam no trabalho do corte da cana, viviam de pequenos trabalhos informais. Estabeleciam a criação de animais de pequeno porte e plantação de subsistência nos períodos de entressafra. A pesca desenvolvida de forma artesanal e rudimentar era fonte de renda complementar muito utilizada pelos que não possuíam emprego formal.

O tempo do laranjeirense era marcado pelo seu calendário festivo, dividido durante os meses do ano, de modo que havia celebrações voltadas para ritos religiosos cristãos e afro-brasileiros. As festas em Laranjeiras atualizavam o passado de formação de bases raciais, seguramente, uma história de conflitos e alianças entre brancos e negros, através de "uma complexa e intricada trama de

1 Referente aos dados do IBGE Censo 2010. Acesso: 12/04/2013. Disponível em 
oposições e conivências, de ódios e paixões, de repugnâncias e acolhimentos" (DANTAS, 1988: 14). Porém, como qualquer contradição houve aproximações em vários momentos, fortemente caracterizado nas festas e ritos religiosos.

Segundo Oliveira (2007) a produção do espaço religioso cristão abrangeu grande parte do território de Laranjeiras, onde a elite açucareira dos séculos XVII, XVIII e XIX, com o apoio de vigários do Vale do Cotinguiba, construiu diversas capelas nos engenhos, em sua maioria, através do uso da mão de obra de escrava. O território geográfico de Laranjeiras era preenchido marcadamente por edificações ligadas à religiosidade cristã, como: Igreja Senhor São Pedro da Ilha, Igreja Senhor da Cruz, Igreja São Benedito e Nossa Senhora. do Rosário, Igreja do Bom Jesus dos Navegantes, Igreja de N. S. da Conceição de Comandaroba, Igreja de N. Sra. da Conceição dos Homens Pardos, Conjunto do Retiro, Igreja Senhor do Bonfim, Igreja Senhor do Bonfim, Igreja Matriz Sagrado Coração de Jesus, Igreja Presbiteriana, Capela Santaninha.

As primeiras políticas públicas de preservação em Laranjeiras datam dos anos 1940, através de processos de tombamento pelo Serviço do Patrimônio Histórico e Artístico Nacional (SPHAN). A Igreja Matriz do Coração de Jesus, o conjunto de casa e Capela do Engenho Retiro, a Igreja de Comandaroba e a capela do Engenho Jesus, Maria e José, foram as edificações tombadas em 1941. Algumas dessas igrejas mantinham suas atividades de cultos religiosos regularmente, porém outras estão em estado de arruinamento. Geralmente em péssimo estado de conservação, buscou-se através do tombamento, um meio de "salvar" os bens edificados do arruinamento.

Outro elemento simbólico de referência era a presença de religiosidades de matrizes africanas. Na cidade havia o terreiro autodenominado de nação nagô Irmandade Santa Bárbara Virgem considerado um dos terreiros mais antigos e influentes da cidade. A antropóloga Beatriz Dantas (1988: 135) pesquisou o terreiro e seus envolvidos nos anos setenta e oitenta do século passado. Através da biografia da então lôxa Umbilina de Araújo apontava que a líder do terreiro nagô considerava à "exceção do catolicismo", as demais formas religiosas de matrizes africanas na cidade incompatíveis com os princípios de pureza respeitados pelo nagô. Segundo relatos do livro, entendia a reverenciada yalorixá que os malês em Laranjeiras eram considerados misturados, porque cultuavam seus ritos com elementos sincréticos, como: toré, umbanda, caboclos, e, por isso, considerados "impuros". A forma possível de trânsito para ser iniciado no terreiro nagô, segundo relato de Umbelina de Araujo, era a condição de ser batizado na Igreja Católica.

O terreiro considerado impuro pela lôxa nagô era a Sociedade de Culto Afro Brasileiro Filhos de Obá 2, um dos mais antigos3 de Sergipe. Importante referencia religiosa da cidade, o terreiro incorporou em seus ritos outras religiosidades como o ketu, ijexá e elementos da Umbanda. O seu caráter sincrético era mal visto na cidade. Havia perseguição e violência policial empregada contra o terreiro no período do Estado Novo, sobretudo através do interventor federal em Sergipe nos anos trinta do século passado (DANTAS, 1988: 222).

A relação de solidariedade e respeito compartilhada entre as religiosidades católica e as religiosidades de matrizes africanas era expressa nos ritos festivos. As festas religiosas no município expunham o tempo na relação dos grupos e

\footnotetext{
${ }^{2}$ Bem Cultural incluído na lista do IPHAN - no de processo 1340 - desde 1994 com processo em situação de instrução. Disponível em: http://portal.iphan.gov.br/pagina/detalhes/126. Data de acesso em : 02/07/15.

${ }^{3}$ Segundo Inventário de Referencias Culturais realizado em Laranjeiras no ano de 2007 e 2011 Código da Ficha UF:SE; Sítio: LAR; Loc: CEN; Ano 11; Ficha F30; ${ }^{0} 28$.
} 
indivíduos entre si. Durkheim (1989: 39) entendia que não se pode conceber o tempo senão com a condição de distinguir nele momentos diferentes. O tempo é organizado e pensado coletivamente pelos envolvidos em uma mesma realidade social, onde o "calendário exprime o ritmo da atividade coletiva, ao mesmo tempo que assegura sua regularidade que corresponde à periodicidade dos ritos, das festas e das cerimonias públicas”. Marcel Mauss (1981: 119) discípulo de Durkheim, via no calendário a expressão da tradição através da memória social, com organização das sequencias das ocupações. Para Le Goff (1990: 518-521) o calendário entrecruza dois tempos: a dialética do tempo livre e do trabalho. Estes autores debateram o calendário e a divisão do tempo e sua organização, e os folguedos folclóricos apresentavam o tempo festivo na estrutura social de laranjeiras através de performance, temporalidade e narrativa preenchendo o calendário anual da cidade com ritos que evidenciavam como os laranjeirenses se orientavam no tempo, a partir de seus ritos festivos.

A celebração desta relação compartilhada entre as religiosidades católica e as de matrizes africanas era expressa através da Festa de Reis/Encontro Cultural e a festa dos Lambe-Sujos e Caboclinhos. A primeira era comemorada no dia o6 de janeiro, consagrado como referência ao dia de louvação aos reis magos. Já a festa dos Lambe Sujos \& Caboclinhos apresenta em seu núcleo narrativo o combate entre representações de negros, conhecidos como "lambesujos", e representações de indígenas, chamados de "caboclinhos". Presentes na memória coletiva dos laranjeirenses, os grupos se caracterizavam de forma distintas e enfatizavam ações jocosas diversas, durante o segundo domingo do mês de outubro. Representavam episódios da escravidão e as revoltas negras no Vale do Cotinguiba, histórias que fazem parte do imaginário local, com ênfase na narração de conflitos nas fazendas de cana de açúcar existentes na região, entre os séculos XIX e XX.

Laranjeiras possuía uma variedade de manifestações culturais de tradição popular. Difícil sistematizar essa informação, ainda mais considerando a deficiência de dados sobre a rica e vasta cultura popular brasileira. Entretanto, conhecido seu potencial cultural, acentuado por um calendário preenchido por festas e manifestações culturais tradicionais, tanto de relevância nacional, quanto de expressão local. Os folguedos mostravam como os laranjeirenses viam sua cultura, e como fazia sentido a operacionalização. E, aqui, o meu papel enquanto antropólogo foi interpretar as evidências simbólicas (OLIVEIRA, 2007: 15). Assim, o tempo festivo era diferente, porém o espaço era o mesmo. A arena festiva em que se apresentavam os folguedos em suas ações rituais eram as ruas da parte histórica da cidade para ambos os grupos. Os tempos distintos do calendário religioso local representavam a polaridade onde a Chegança era associada a pureza e remetia aos valores cristãos; e os Lambe-Sujos associados ao poder liminar e transgressor.

O tempo na Festa de Reis, no mês de janeiro, era celebrativo e devocional. Uma festa onde desfilavam grupos folclóricos considerados prestigiados em hierarquia. Mantinham relação estreita com as religiosidades e instituições locais. Por outro lado, os Lambe-Sujos representavam episódios da escravidão, de labor, revoltas e a resistência negra no Vale do Cotinguiba. Os dois momentos distintos do calendário festivo laranjeirense expressavam uma relação dialética entre estrutura social e liminaridade. Por estrutura social, segundo Victor Turner (1974), seria posições formais de status expressas no cotidiano ordinário. E a "liminaridade" o instrumento ritual que afrouxa, 
flexibiliza, relativiza os requisitos de status e estratificação particular da agência estrutural.

As festas de Reis e a festa dos Lambe-Sujos e Caboclinhos, aparentemente configuravam-se polarizadas mediante a relação entre o lado religioso e o lado lúdico, geralmente visto como transgressor. Na verdade, grupos folclóricos celebrando em aparente dualidade polarizada. É neste ponto que o artigo se prenderá: na inter-relação entre os folguedos, sobretudo se entendermos a temporalidade na narrativa de seus personagens, expondo o sentimento de identificação e pertença com referências simbólicas: folguedos vividos como elementos da sua própria história.

\title{
Noção de mestre na narrativa folclórica
}

Mario de Andrade (1982) em sua viagem à região Nordeste do país, no final da década de 1920 no estado da Paraíba, descreveu o significado da palavra "mestre" em suas pesquisas sobre danças dramáticas nos folguedos populares:

\begin{abstract}
Derivado dos costumes dos janeireiros, a figura do Mestre, que com este nome principal, ou com outro, é comum a todas as danças dramáticas. O Mestre é o diretor do espetáculo e do Rancho, puxador das cantorias comumente, organizador e mandachuva. No geral, ele funde a sua posição técnica de Mestre do bailado com a de um dos personagens principais da parte dramática. Nos Congos, por exemplo, ele é quase sempre o secretário dos Reis, e nas Cheganças, o Mestre Piloto.

[...] Ele é o diretor do espetáculo e puxador das cantorias. Não raro ele tem uma ascendência moral bastante curiosa, sob certos aspectos muito fortes e noutros irrisória, que o assimila extremamente a certas formas de chefia próprias das culturas primitivas. É evidente que se trata de uma tradição herdada entre nós da evasiva ascendência exercida pelos morubixabas sobre as tribos e, em principal, dos reis negros fictícios, consentidos e utilizados na Colônia pelos chefes brancos, e que até hoje ainda permanecem como costume deteriorado em várias partes do país. O exercício de sua chefia, pelo mestre das danças dramáticas e de certos grupos dos dançadores do samba rural, é perfeitamente assimilável ao desses reis negros do Brasil e ao dos morubixabas. Se o valor político é nulo, muito dúbia e prepotência moral que não raro se resume à distribuição e limitação da cachaça sobre os dançadores de ranchos dentro do cerimonial da festa é um poder absoluto que ninguém se lembra de discutir (ANDRADE, 1982: 65).
\end{abstract}

Em que pese todo o debate acerca dos Estudos de Folclore como elemento do Pensamento Social Brasileiro, o termo "mestre" não se torna especificamente o tema dos folcloristas. Porém, é citado nos trabalhos, geralmente, como "líder" da brincadeira. Nos Estudos de Folclore, o enquadramento do fato folclórico na busca de se tornar "científico" identifica, segundo Carneiro (2008:129), "em conjunto, uma série de maneiras de sentir, pensar e agir características das camadas populares nas sociedades civilizadas". O "mestre" na literatura folclórica geralmente é descrito pela posição que ocupa na brincadeira, "aquele que se distingue após uma longa trajetória no desempenho de ofício particular" (ABREU, 2004: 62), como aquele responsável pela função de dominar tudo aquilo que envolve o folguedo e sua ação.

Associado também como aquele que detém todo conhecimento na descrição das falas, os toques, melodias, sonoridades, danças, cantos, dos personagens, da história envolvida, da forma como é performatizada, dramatizada, enfim, ele é responsável por tudo aquilo que envolve os folguedos em suas particularidades e sua transmissão. A despersonalização define, segundo a descrição do importante estudioso paulistano, a trajetória e qualidades de um "mestre", a partir de critérios, como: de longevidade, 
comando, aprendizagem familiar, desempenho harmônico e transmissão romantizada do ofício, nas atividades e relações entre mestres e aprendizes.

Algumas questões se mostram. Nos estudos de folclore dos anos 1960, segundo Vilhena (1997) quando houve intenção de situar o Folclore nas ciências antropológicas e culturais, houve a adaptação do folclore à teoria funcionalista durkheimiana. Isto acarretaria ao estudo, incluir técnicas, classificações e características, onde o folclore passou a ser visto como um "fato social", dinâmico. O "fato folclórico", possui características, e precisa ser ao mesmo tempo: tradicional em seus elementos formadores, anônimo e popular. (CARNEIRO, 2008: 132). Dessa maneira, o folclore é visto como "dinâmico em sua essência", como elemento coletivo, um traço cultural presente na sociedade.

Está forma coletiva, geral e abstrata de apreensão do fato folclórico mesmo vivenciando uma "experiência particular, no momento exato em que são sujeitos das experiências, são vistas como elos entre o passado e o futuro" (ABREU, 2004: 61). Mesmo assim, estabeleceu formas gerais sobre o modo de ver o todo. Não deu a mesma atenção as partes em ação na brincadeira. Essa forma de observar o folclore, considero que ultrapassou gerações, estabelecendo formas de interpretar o mundo. Entendo que para alguns pesquisadores em determinado momento histórico, entre os anos 1950-60, as difíceis características que definiram o folclore, construída através de duros debates nos Congressos de Folclore, em torno daquilo que fosse o "tradicional", o "anonimato" e o "popular"; estabeleceram como barreira, uma fronteira que não permitiam ir além do que existia além de uma ideia de função e descrição geral do folguedo.

A maneira como entendiam os pesquisadores folcloristas impediam em seus trabalhos, do popular individualizar-se. Tudo que tinha um cunho individual, ao folclorizar-se, passaria por um processo de despersonalização, o que lhe restituiria ao anonimato. Porém, a compreensão dos folguedos Laranjeirenses a partir da discussão entre narrativa e temporalidade envolve entendimento do folclore, segundo antropóloga Maria Laura Cavalcanti (2012: 151), como elementos da vida social:

\begin{abstract}
carregados de sentidos e dimensões múltiplas, construídos na relação entre e com distintas forças sociais, que se unem e se contestam situações variadas, que entram umas com as outras em diálogo, cuja acepção atual vai "além da prática, da memória e da visão dos próprios brincantes que o realizam, integram esse fato vivo os muitos textos que já o estudaram, as políticas culturais e turísticas que a promovem, as prénoções e expectativas de nossas pesquisas.
\end{abstract}

Embora a descrição de Mário de Andrade forneça pistas, é preciso considerar todas as ressignificações e motivações da transmissão cultural que comportam a criatividade pessoal do indivíduo com seu brinquedo. Afinal, o que quero dizer é que os termos "anonimato", "tradicional" e "popular", estão sendo manipulados e mediados pelos "mestres" dos folguedos populares em situações relacionais. A criatividade da ação de "mestres" e brincantes, através de conjunto ordenado de ações, mantém a cultura em processo constante. José Ronaldo de Menezes, Zé Rolinha, é tomado aqui como fio condutor em seu papel de mediador entre diferentes mundos, o que lhe permite operar a construção de ser "mestre" na cultura popular contemporânea.

Em evidência, sua trajetória no meio sociocultural, permeado por diferentes atuações mediadas por diferentes níveis que envolve experiências, conflitos, campo de possibilidades, ajustes e choques entre habitus confome trânsito no campus e seus dramas e conflitos. Entender ser "mestre" é aquilo 
que o torna especialmente exposto a experiências muito diferenciadas, na medida em que se desloca e tem contato com universos sociológicos, estilos de vida e modos de percepção culturais distintos, e mesmo constrastantes.

\section{A pessoa-personagem Zé Rolinha}

José Ronaldo nasceu no munícipio de Laranjeiras em 1963. A vida econômica difícil da família fez com que os anos necessários dedicados aos estudos dessem lugar ao trabalho no corte da cana nos campos das zonas rurais do Vale do Cotinguiba. Sua família oriunda do povoado Salgueiro, localizado entre Japaratuba e Santo Amaro das Brotas, dois municípios limítrofes. José Ronaldo falou que o primeiro membro da família a chegar a Laranjeiras, no final da década de 1920, fora seu bisavô conhecido como Quereu Quereu, pois tinha a função de trabalhar na fornalha de cana nas fazendas, na parte da queima do produto. José Ronaldo lembrou:

\section{O meu bisavô tempo depois, trouxe parte dos filhos, sendo um deles o meu avô que tinha o ofício de artesão que o produto é a argila. Trabalhava fazendo telhas $e$ tijolos que serviram na construção civil lá em Aracaju”}

O pai de José Ronaldo era da polícia militar e trabalhava na cidade de Aracaju. A mãe desempenhava a função de doméstica em Laranjeiras. Nas memórias a estratificação entre brancos e negros em Laranjeiras reverberava nas conversas com Zé Rolinha, ao acionar os limites impostos pela elite local à sua época de criança (finais dos anos de 1960), proibindo o trânsito de pessoas negras em determinadas áreas da cidade. As crianças pobres da Rua da Alegria4 e da rua do Boquim, área periférica e local tradicional de comemoração de folguedos e brincadeiras populares, não podiam passar na rua Jackson Figueiredo, local de concentração de moradias de pessoas de "elite branca" com "alto poder aquisitivo e político". Assim, essa estratificação social sentida gerou ações, estratagemas heterogêneos de apropriação, resistência e afirmação canalizadas nas expressões culturais, nos folguedos populares.

José Ronaldo se mostrou muito reservado em nossas conversas quando estávamos a sós. Porém, quando envolto por mais pessoas, geralmente folcloristas, professores, gestores culturais, em dias das festas dos folguedos ou em algum evento sobre cultura popular em que era palestrante, ele se transformava e o diálogo acontecia de forma mais relaxada e descontraída. Durante a pesquisa, conforme a confiança se estabelecia, ouvi muitas histórias sobre os folguedos. Narradas de modo mais espontâneo, elas se mostravam complementares e mais profundas do que aquelas com as quais respondia às minhas indagações, das primeiras vezes em que nos vimos. Lembro-me das barreiras: falas didáticas que expunham de forma curta e direta o enredo da atuação dos folguedos, realçando a atuação de certos personagens e a estrutura hierárquica dos grupos; citando breves passagens de músicas e falas; mostravase sempre impaciente, incomodado com minhas perguntas.

Conforme nosso contato prosseguia, percebi que em determinadas situações suas narrativas sobre os folguedos abordavam sua aprendizagem na cultura popular local. Falava das tensões e conflitos no processo de transmissão e aprendizagem da cultura popular; de sua percepção acerca da importância no combate ao racismo e, no meio de tudo isso, os folguedos emergiam como um 
elo entre dois mundos, passado e presente, não desconexos onde a tradição dos folguedos impulsiona a construção do novo. Suas falas sobre os folguedos, invariavelmente, relacionam experiências individuais, folguedos e a história social de Laranjeiras, elementos da vida do laranjeirense em sua formação. A performance narrativa de Zé Rolinha associava-se ao "Narrador", de Walter Benjamin (1980), aquele que retira de sua experiência o que conta. O ato de narrar do Zé Rolinha é entendido como uma estratégia articulada pela memória que torno de experiências compartilhadas em interação com distintos níveis socioculturais de classes, gênero, projeto, campo de possiblidades e geração. Assim, o narrador Zé Rolinha, constitui sujeito especial de um tipo de comunicação que articula diferentes temporalidades, com trânsitos entre distintas esferas socioculturais.

Sua narração envolve folguedos como representações de um passado sobre Laranjeiras que abrange patrimônio e raça. Além de sua inserção desde criança no universo da cultura popular local, posteriormente, suas experiências legitimavam sua condição de líder perante os laranjeirenses construídas através de mediações com elementos de referências socioculturais advindos de outros circuitos culturais: a) Foi membro representante do colegiado Nordeste da Setorial de Culturas Populares, do Conselho Nacional de Política Cultural do Ministério da Cultura (MinC), entre os anos de 2010 e 2014; b) Atuou junto aos folcloristas e pesquisadores de várias áreas que frequentam regularmente Laranjeiras desde a instituição do Encontro Cultural em 1976; c) Produziu projetos para concorrer em editais públicos e privados em busca de captação de recursos e incentivos baseados em leis de financiamento cultural; d) Sua liderança extrapola seus próprios folguedos, e se exerce entre os demais líderes de outros folguedos como representante eleito dos grupos folclóricos da cidade de Laranjeiras; por fim, e) teve a experiência de gestão cultural, com o cargo comissionado na prefeitura municipal, como coordenador da Casa de Folclore local. Outrora, inimagináveis tais áreas de atuação servirem a um brincante.

Seu papel mediador envolvia, invariavelmente, performance, trajetória, experiências, um campo de possibilidades se quisermos entender o que acarreta a palavra "mestre" neste contexto, tanto no folguedo Chegança, como no Lambe-Sujos. Agia como guardião de memória social descrevendo e ordenando os fatos de acordo com as tradições estabelecidas. Um conhecedor da memória que auxilia o entendimento do estudo da memória social de Laranjeiras, cotejado com a memória e oralidade de alguns líderes de folguedos, como meio fundamental de abordar problemas do tempo e da história. E, obviamente, não descartando a criatividade envolvida na ação e performance do Zé Rolinha.

\section{A transmissão do aprendizado com base em tensões e conflitos}

Nossas conversas foram baseadas em lembranças de suas experiências quando criança, no aprendizado com outros líderes de folguedos. Os relatos sobre as motivações de Zé Rolinha no ofício dos dois brinquedos, trouxeram personagens de outrora, ações de antigos líderes de importantes folguedos da cidade que o influenciaram na trajetória dentro dos brinquedos. Interagiu com importantes mestres e grupos folclóricos locais de diferentes gerações. Esse aprendizado o auxiliou naquilo que entendia como a "adequada aplicação da conduta no brinquedo", e como transmitia para os brincantes. Robustece sua 
narração com elementos tradicionais, evocando de tempos passados, misturando com aspectos individuais para ter se tornado "mestre".

Ressalto dois elementos sobre o que considera "mestre": a) primeiro como já havia observado Dantas (2013), não era necessário ser o mais velho para ser o responsável pelos folguedos. $\mathrm{O}$ saber tradicional não tinha necessariamente a ver apenas e somente com idade; e, b) segundo, as tensões e conflitos aparecem como estratégia de ensino/aprendizado. Fato reafirmado por Zé Rolinha que "reproduz" o que aprendeu, seguindo a linha de seus "mestres anteriores. Para ele: "os líderes desse período ensinavam através do "carrancismo", onde era comum o líder do folguedo, às vezes estar errado, e mesmo assim, querer impor sua vontade”.

As tensões na relação do líder com os brincantes são constantemente ressaltadas por ele. Atribui os atritos à diferença entre gerações. No caso dos Lambe-Sujos (grupo), o conflito e a tensão são elementos da própria performance desenvolvida na brincadeira. Zé Rolinha entendia que a forma como agiam os mais antigos líderes dos brinquedos na transmissão, avisando: "como deveríamos aprender a dançar, a tocar e a cantar era muito dura, era na base da humilhação que se aprendia o respeito". As tensões na dinâmica de aprendizagem exercida pelos mais antigos líderes serviram de modelo executado pelos atuais no processo de transmissão/aprendizagem.

Para ele, a forma "dura", com broncas e humilhações adequa-se como forma peculiar de estabelecer continuidade e resistência, estimulando o brincante a desenvolver sua identificação com o brinquedo e, consequentemente como prevenção para alguma eventual cisão no grupo. Dizia: "havia alguns que não gostavam de passar aquilo que sabia... os mestres não passavam o conhecimento da brincadeira, nadinha para ninguém". As lembranças emergiam junto com fragmentos e situações pessoais que iam compondo sua experiência inicial no conhecimento dos folguedos, e ao mesmo tempo, se constituíam em elementos de sua vida social. Avento a possibilidade de que a tensão comum no processo de transmissão, entre os brincantes mais velhos e mais novos, talvez resultasse do receio dos lideres mais antigos que buscavam preservar a liderança pessoal, estabelecendo cada um, maneiras particulares com as quais conduzia seu brinquedo.

No final dos anos 1990, a cidade de Laranjeiras passou a ser vista como abrigando um conjunto de criações culturais tradicionais e seus grupos folclóricos ganharam maior atenção recebendo recursos oriundos em projetos com incentivos fiscais. O Inventário Nacional de Referências Culturais, metodologia do Iphan de mapeamento e produção de conhecimento sobre o patrimônio cultural, foi realizado em Laranjeiras município entre os anos de 2009 e 2011. Nas etapas de Levantamento Preliminar e Identificação, o Inventário identificou bens e práticas culturais produzidos por diversos grupos sociais que com eles se identificam, se tornando referência para a trajetória de vida dos laranjeirenses.

Nesse novo contexto, Zé Rolinha passou a ser convidado para fóruns de cultura e outros espaços oficiais de debate sobre a cultura popular. Como membro representante do nordeste do Colegiado Setorial de Culturas Populares do Conselho Nacional de Política Cultural, sob a coordenação da então Secretaria da Identidade e da Diversidade Cultural (SID), estimulou-o a conhecer melhor os incentivos fiscais para iniciativas culturais, mecanismos de captação de recursos, envolvimento da iniciativa privada no intuito de potencializar a cadeia produtiva da cultura local. Participou de curso de 
capacitação que o auxiliou na organização de associação de grupos folclóricos, onde tornou-se representante dos grupos folclóricos de Laranjeiras, legitimado pelos demais mestres dos folguedos tradicionais da cidade para representar os interesses de todos. Tais iniciativas lhe renderam visibilidade e ampliação de rede colaborativa, principalmente na manutenção dos folguedos.

Esse protagonismo exercido por Zé Rolinha sofria a pressão dos anseios de brincantes por maiores incentivos públicos na cultura popular, desse modo, passou a questionar o poder institucional. Questionava se o "saber" parecia pertencer apenas aos "mestres" da academia, no caso Universidades. Na contramão, reivindicava o reconhecimento e o poder de fala e atuação dos próprios brincantes nos espaços públicos de discussão. Essa postura inflamava os presentes e incomodava o poder público local, sempre cobrado pelos pesquisadores e plateia, para maiores incentivos na cultura popular local. Estas questões levantadas por Zé Rolinha, e tantos outros antes dele, culminaram na criação da Lei Municipal $\mathrm{n}^{0}$ 909/2009 de 29 de outubro de 2009. A lei municipal institui o registro dos "Mestres dos Mestres da Cultura" na cidade de Laranjeiras. Luciana Aguiar (2011) observou como a implementação das políticas de patrimônio em nível municipal, introduziram em 2010, diferenciações entre os produtores da cultura popular em Laranjeiras:

\footnotetext{
Ciza, Zé Rolinha e Nadir, por exemplo, são "pessoas do folclore”, como se diz em Laranjeiras, que possuem grande influência e prestígio nos meios institucionais mais amplos da cidade. Pela maneira como se colocam frente a essas instituições eles conseguem vantagens para seus grupos que outras "pessoas do folclore" não conseguem (AGUIAR, 2011: 131).
}

Um brinquedo folclórico demanda uma coletividade com funções distribuídas hierarquicamente entre personagens, com funções e performances distintas, que encenam um enredo que serve de fio condutor para o cortejo em dia ritual específico. No entanto, a mesma coletividade, atribui autoridade legítima a seu líder por entendê-lo apto a exercer a função de "mestre", portanto, representar o grupo. O benefício adquirido pela Lei "Mestres dos Mestres", bem como outros prêmios despertou questionamentos entre o papel do indivíduo como "mestre", e o grupo de brincantes no folclore laranjeirense. Em 2014, pude acompanhar a inserção de novos brincantes para substituir os que haviam saído por conta dos conflitos ocorridos. O rompimento com os integrantes mais antigos obrigava-o também a desgastar-se mais.

Empenhava-se com mais esforço em transmitir o conhecimento sobre as ações rituais desempenhadas pelos personagens dos folguedos aos novos brincantes, isso com poucos meses para iniciar o Encontro Cultural daquele ano. Nas políticas de incentivo às comunidades tradicionais torna-se muito importante a clareza na destinação dos recursos e o monitoramento do repasse nos casos previstos de modo a avaliar5 sua eficácia e legitimidade na visão do grupo. A noção de patrimônio imaterial e a implementação das políticas públicas pertinentes trouxeram um novo modo de atuação sobre os circuitos da cultura popular, com a multiplicação de projetos, instituições, espaços e equipamentos.

Tudo isso alterou o modo de atuação dos agentes envolvidos na cultura, tanto no que diz respeito aos procedimentos para obtenção de recursos quanto ao processo de gestão. Atualmente, com as possibilidades de empreendedorismo

5 Há muitos pontos obscuros na Lei "Mestre dos Mestres", por exemplo, não permite ao brincante beneficiado contrapartida, indo contra a ideia de Referência Cultural com recomendação da UNESCO - "Patrimônio Vivo", onde a sociedade e os indivíduos, tem responsabilidades, são coparticipes em estabelecer forma de sustentabilidade do seu bem cultural. 
e geração de renda proporcionada pelas ideias da economia da cultura e a economia criativa, há "exigências" para que os "mestres" se afastem do "amadorismo" e do "improviso" (AVELAR, 2008), presentes na cultura popular, e se tornem agentes culturais. Nos últimos anos, o improviso do mestre da cultura popular vem cedendo espaço para práticas menos empíricas. Percebe-se que, no meio das políticas públicas de cultura, é imprescindível dominar outras linguagens e buscar informações complementares àquelas do dia-a-dia.

\title{
A Chegança além-mar
}

Conversamos sobre sua experiência com as festas de mouros e cristãos na Europa. Por sua atuação na Chegança Almirante Tamandaré, Zé Rolinha recebeu convite para ir à Espanha como palestrante de um seminário sobre "Tradições Folclóricas Brasileiras", na Universidade de Alicante, em maio de 2012. Era a terceira vez que recebia convite para participar desse evento, porém a ausência de recursos impediu as duas primeiras tentativas. Contudo, no ano seguinte concorreu e foi contemplado em um edital da Secretaria de Estado da Cultura de Sergipe o que viabilizou recursos para passagens aéreas. O intercâmbio com as festas de mouros e cristãos na Europa, onde supostamente a chegança tem sua origem, trouxe reflexões, estimulou o estranhamento sobre seu brinquedo e sobre sua atuação como "mestre":

Essa experiência expôs Zé Rolinha em sua capacidade para absorver, rever e, quem sabe, reinventar sua visão sobre o brinquedo e, consequentemente, a ideia de tradição que acompanha. É dessa forma que pessoa-personagem Zé Rolinha se constrói nesses cotejamentos, pensamento crítico sobre seu folguedo, sobre a noção de mestre, sobre a tradição, fato que exemplifica o lado vivo e dinâmico do folguedo, refutando os críticos que temem a cultura popular "acabar" por conta dos processos modernizantes e do ritmo acelerado da globalização.

\begin{abstract}
Vi que a pessoa lá em Alicante, que não é uma cidade grande como eu pensava, viu meu rapaz? Lá, as pessoas participam mesmo! Era muita gente, mesmo. Mais de mil pessoas sendo somente os comparsas, que lá são os componentes dos mouros $e$ cristãos. Tudo vestindo cada roupa bonita que aqui nós não temos condições de ter. Não tem nem comparação as roupas com as nossas. Nem chega nos pés das deles. Ave, Maria! Sairia muito caro para gente comprar. E ainda tinha o povo, que ficava assistindo tudo com muitas palmas, e uma alegria, vendo o desfile passar [as representações de cristãos e mouros] nas ruas. É muito lindo! E eles respeitam muito o espaço sem invadir o espaço dos grupos (Zé Rolinha, conversa realizada em 21-08-2014).
\end{abstract}

Em sua construção discursiva, daquilo que entendia ser a atuação de um "mestre" da Chegança, não se utiliza apenas de uma narrativa tradicional, com base em um passado histórico de memórias e oralidade, mas envolve a percepção de suas experiências. Assim, em suas reflexões e falas sobre o folguedo não lhe interessava a busca de uma suposta "origem", que tanto atiçou a curiosidade dos folcloristas, porém acreditava que:

Essa é uma "busca sem resposta", ninguém, nem o mais esperto de todos conseguirá lhe responder, meu filho! Cada lugar tem sua forma de brincar a chegança, e na Espanha também tem seu jeito. Nós temos as nossas e são as nossas. Mesmo que afirmem que a nossa Chegança seja de algum lugar, até da que vi na Espanha, que seja. Mas a verdade é que são muito diferentes, até no modo de se expressar. Na verdade, não sei lhe dizer se uma veio da outra. O que sei é aquilo que os mais velhos me diziam. O que aprendi? Aquilo que eu via e escutava dos outros mestres $e$ 
de minha família. E é isso que eu mostro para você, o que sei e da forma como eu entendi e repasso.

\section{Considerações Finais}

A compreensão aqui proposta da noção de mestre tem menos a ver com uma ideia de "autenticidade" ou de uma integridade orgânica ligada ao seu discurso, como uma tradição balizadora que o define por si só. Interessa-nos mais a apropriação por Zé Rolinha do termo como algo contraditório, composto de elementos antagônicos, conflitivos e instáveis. O termo "mestre" tem a ver com o lugar e a posição desde onde é acionado, ou seja, ele não está no "interior de sua forma tradicional" como definem narrativas dos estudos de folclore e, muito menos em sua condição de "patrimônio cultural".

Dessa forma, o termo "mestre" por tal posição associa-se ao exercício da mediação entre mundos, permeado por elementos socioculturais que o configuram e reconfiguram o campo de possibilidades fluido e permeável, com seus habitus, inserido em práticas diversas que se articulam que o torna atento às mudanças de seu tempo. São reviravoltas de um sistema cultural vivo e dinâmico. A sua relação com as normas sociais implementadas pela elite política e intelectual é uma maneira de reverter as regras do jogo.

A sabedoria popular no uso de táticas no fazer de sua arte ressalta maneiras variadas de transitar, utilizar, mediar o sistema vigente, procurando ao menos através de "qualificações", equilibrar-se entre forças assimétricas. Assim, através de relação com Zé Rolinha entendi que a posição de "mestre" não é somente posição de resistência, uma disposição deliberada meticulosamente pensada na direção contra hegemônica, mas seu entendimento vai além. Tem a ver com trajetórias envolvendo as múltiplas realidades que influenciam as experiências da pessoa, do indivíduo na construção de sua subjetividade e, consequentemente, a exposição sobre a sua realidade, o que pode ocorrer por vezes de forma dramática através de múltiplas interações.

\section{Referências Bibliográficas}

ABREU, Regina. Performance e Patrimônio intangível: os Mestres da Arte. In: João Gabriel Teixeira, Marcus Vinícius Carvalho Garcia e Rita Gusmão. (Org.). Patrimônio Imaterial, Performance cultural e retradicionalização. 1 ed. Brasília: UNB, 2004, v. 1: 1-200.

AGUIAR, Luciana de Araújo. Celebração e Estudo do Folclore Brasileiro: $O$ Encontro Cultural de Laranjeiras/Se. Dissertação em Antropologia. PPGSAIFCS/UFRJ, Universidade Federal do Rio de Janeiro, 2011.

ANDRADE, Mário de. Danças Dramáticas do Brasil. (Org) Oneida Alvarenga. 2 ed. Brasília, 1982.

AVELAR, Rômulo. O avesso da cena: notas sobre produção e gestão cultural. 1.ed. Belo Horizonte: Ed. do Autor, 2008. 
CARNEIRO, Edison. Dinâmica do Folclore. São Paulo: Martins Fontes, 2008.

CAVALCANTI, Maria Laura. Reconhecimentos: antropologia, folclore e cultura popular. Rio de Janeiro: Aeroplano, 2012.

DANTAS, Beatriz Góis. Vovó nagô e Papai Branco. Rio de Janeiro: Graal. 1988.

- Mensageiros do Lúdico: mestres de brincadeiras em Laranjeiras. Criação: Aracaju, 2013.

GEERTZ, Clifford. Interpretação das Culturas. Rio de Janeiro: LTC, 2008.

LE GOFF, Jaques. Historia e Memória. Campinas, SP Editora da UNICAMP, 1990.

LYOTARD, J-F., THEBAUD, J-L. Just Gaming. Minneapolis: University of Minnessota Press, 1985. pp. 34 e 39.

MAUSS, Marcel. Ensaios de Sociologia. São Paulo, Perspectiva, 1981.

REDES. Relatório Final Fase 1 - Território Sergipano município Laranjeiras. Redes para o Desenvolvimento Sustentável. Giral Viveiros de Projetos, Brasília, 2011.

TURNER, Victor. O Processo Ritual - estrutura a antiestrutura. Petrópolis: Vozes, 1974.

VELHO, Gilberto. Biografia, Trajetória e mediação. In: VELHO, Gilberto \& KUSCHNIR, Karina. Mediação, Cultura e Política. Rio de Janeiro; Aeroplano, 2001.

Recebido em 11/o6/2017.

Aprovado em 24/07/2017. 